\title{
APPLICATION OF PERMEABLE ASPHALT MIXTURES IN AIRPORT PAVEMENTS
}

\author{
Yoshitaka HACHIYA ${ }^{1}$, Shisheng $\mathrm{WU}^{2}$ and Osamu TAKAHASHI ${ }^{3}$ \\ ${ }^{1}$ Member of JSCE, Dr. Eng., Chief, Runways Laboratory, Port and Harbor Research Institute, Ministry of Land, \\ Infrastructure and Transport (1-1, Nagase 3, Yokosuka 239-0826, Japan) \\ ${ }^{2}$ Dr. Eng., STA Fellow, Runways Laboratory, Port and Harbor Research Institute, Ministry of Land, Infrastructure \\ and Transport (1-1, Nagase 3, Yokosuka 239-0826, Japan) \\ ${ }^{3}$ Member of JSCE, Dr. Eng., Senior Research Engineer, Runways Laboratory, Port and Harbor Research Institute, \\ Ministry of Land, Infrastructure and Transport (1-1, Nagase 3, Yokosuka 239-0826, Japan)
}

\begin{abstract}
Water can cause increasingly severe damage to airport pavements as the magnitude and number of aircraft loads increase. A water drainage system can extend pavement life and is recommended for heavyduty airport pavements. Characteristics of permeable asphalt base mixtures and porous asphalt surface mixtures, which are used to remove rainwater from pavement, were studied in laboratory tests. As a result, the applicability of both materials for airport pavements was fully confirmed.
\end{abstract}

Key Words: asphalt mixture, permeability, airport pavement, aggregate, modified asphalt

\section{INTRODUCTION}

Atmospheric precipitation enters pavement structures in several ways, including from the pavement surface through cracks and joints. As water can deteriorate pavement, drainage is one of the most important factors in pavement design. Unfortunately, this aspect has scarcely interested engineers until recently. However, adequate drainage becomes very significant as the severity of traffic loading increases.

The free water in a pavement can be drained both vertically through the subgrade and laterally through permeable layers. The latter is not required if infiltration into the pavement is less than the subgrade drainage capacity. This might not be the case for airport pavements on ground reclaimed from the sea where the groundwater table remains high. Therefore, a lateral drainage system with a subsurface layer must be provided in heavy-duty airport pavements.

Cedergren ${ }^{1)}$, Forsyth et al. ${ }^{2)}$, Ray and Christory ${ }^{3)}$, and others report that adequate subsurface drainage can extend the life of pavements significantly. Based on such research, the use of permeable asphalt base (PAB) mixtures for road pavements has recently increased in the USA ${ }^{4)}$. Therefore, their applicability for airport pavements was investigated in this study.
As the rainwater must be removed quickly from the surface to retain adequate friction in rainy weather, porous asphalt surface (PAS) mixtures are often adopted to road pavements. Such mixtures have been used in many countries in Europe and the American Continent since the early 1980's. In Japan, their use commenced in the early 1990's and has currently become one of the standard work processes ${ }^{5)}$.

In airport runways, transverse grooving is generally used for the inner portions ${ }^{6}$. To hasten water removal, PAS might be used in the outer portions including shoulders from an economical point of view. The applicability of this method in less trafficked portions of airport runways was examined in this study.

Characteristics of these two types of mixtures on both permeability and strength were studied through laboratory tests. As a result, the fundamental properties of such mixtures were determined.

\section{PERMEABLE ASPHALT BASE MIXTURES}

\section{(1) Material}

A maximum aggregate size of $30 \mathrm{~mm}$ was used 
Table 1 Marshall stability test results of PAB

\begin{tabular}{c|c|c|c|c|c|c}
\hline Case & $\begin{array}{c}\text { Target air } \\
\text { void } \\
(\%)\end{array}$ & $\begin{array}{c}\text { Actual air } \\
\text { void } \\
(\%)\end{array}$ & $\begin{array}{c}\text { Density } \\
\left(\mathrm{g} / \mathrm{cm}^{3}\right)\end{array}$ & $\begin{array}{c}\text { Asphalt } \\
\text { content } \\
(\%)\end{array}$ & $\begin{array}{c}\text { Stability } \\
(\mathrm{kN})\end{array}$ & $\begin{array}{c}\text { Flow } \\
(1 / 10 \mathrm{~mm})\end{array}$ \\
\hline $30-1$ & 20 & 21.2 & 1.987 & 4.0 & 3.22 & 32 \\
$30-2$ & 23 & 23.1 & 1.946 & 3.8 & 2.96 & 29 \\
$30-3$ & 26 & 27.1 & 1.850 & 3.6 & 2.49 & 23 \\
$30-4$ & 29 & 29.0 & 1.805 & 3.5 & 1.69 & 23 \\
$30-5$ & 32 & 32.8 & 1.735 & 2.5 & 1.28 & 17 \\
\hline
\end{tabular}

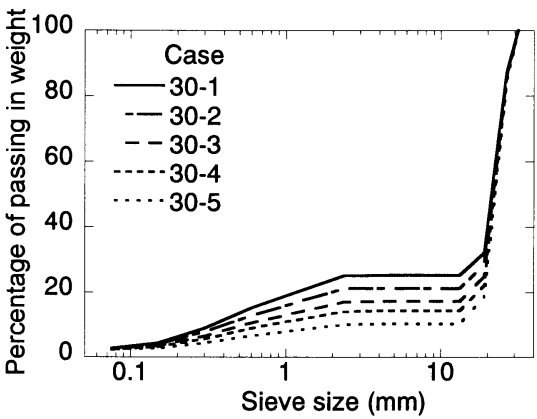

Fig. 1 Aggregate gradation of PAB

Table 2 Characteristics on aggregates of PAB

\begin{tabular}{c|c|c|c}
\hline Case & $D_{\text {mean }}(\mathrm{mm})$ & $D_{10}(\mathrm{~mm})$ & $P_{0.075}(\%)$ \\
\hline $30-1$ & 21.5 & 0.34 & 2.8 \\
$30-2$ & 21.8 & 0.41 & 2.7 \\
$30-3$ & 22.2 & 0.54 & 2.5 \\
$30-4$ & 22.5 & 0.81 & 2.4 \\
$30-5$ & 22.8 & 2.36 & 2.3 \\
\hline
\end{tabular}

for permeable asphalt base (PAB) mixtures; that is, the aggregate consisted of single-sized crushed stone (S-30), coarse sand and filler. Conventional straight $60-80$ asphalt was used.

Five air void ratios $(20,23,26,29$ and $32 \%)$ were selected as target mix proportions. To determine optimum mixtures, tentative proportions with seven combinations of aggregates and three different asphalt contents were evaluated. The mix proportions were finally determined as shown in Table 1, based on Marshall stability tests along with asphalt runoff tests ${ }^{7}$. The gradation and characteristics of the aggregates are shown in Fig. 1 and Table 2, respectively.

\section{(2) Permeability}

Water flow in PAB was investigated experimentally. The factors that influence the permeability were also analyzed.

A series of constant head permeability tests were conducted to measure the permeability of PAB. The apparatus for these tests is shown in Fig. 2. In the test, hydraulic gradients were varied from 0.005 to 1.0 by adjusting the height of the water tank.

Specimens with a diameter of $210 \mathrm{~mm}$ and height of $500 \mathrm{~mm}$ were prepared by compacting in several

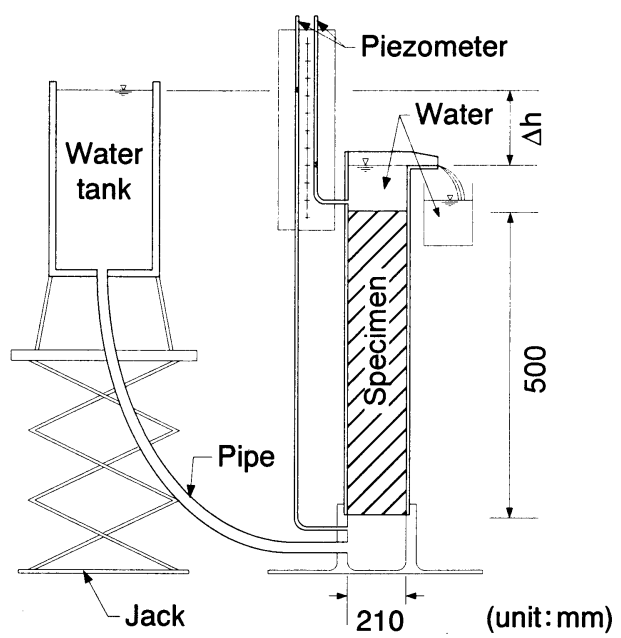

Fig. 2 Apparatus for permeability test

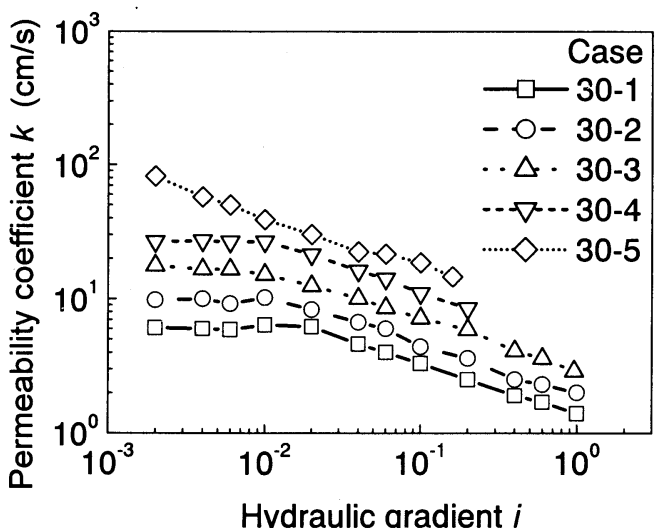

Fig. 3 Results of permeability test for PAB

layers with 50 rammer blow cycles as well as the Marshall stability test. The diameter was appropriate for the maximum aggregate size used in the specimens, while the height allowed the hydraulic gradient to be varied.

The discharge velocity was expressed in a curved form, as a function of the hydraulic gradient for the asphalt mixtures considered. However, this is treated as linear in a low hydraulic gradient range. Therefore, the flow is in a laminar state in this range, while it is in a turbulent state in higher gradients. These conditions are expressed as Equations (1) and (2), respectively ${ }^{8}$.

$$
\begin{array}{ll}
u=k \cdot i & \left(i \leq i_{c}\right) \\
i=c \cdot u^{n} & \left(i \geq i_{c}\right)
\end{array}
$$

where, $u$ : discharge velocity,

$k$ : permeability coefficient, 
Table 3 Characteristics on permeability of PAB

\begin{tabular}{c|c|c|c|c|c}
\hline Case & $k(\mathrm{~cm} / \mathrm{s})$ & $c$ & $n$ & $i_{c}$ & $k_{i=0.015}(\mathrm{~cm} / \mathrm{s})$ \\
\hline $30-1$ & 6.1 & 0.598 & 1.61 & 0.02 & 6.1 \\
$30-2$ & 9.8 & 0.354 & 1.6 & 0.015 & 9.8 \\
$30-3$ & 16.5 & 0.176 & 1.57 & 0.012 & 14 \\
$30-4$ & 26.8 & 0.083 & 1.63 & 0.01 & 22 \\
$30-5$ & - & 0.042 & 1.6 & - & 34 \\
\hline
\end{tabular}

Table 4 Change of discharge time due to loading for PAB

\begin{tabular}{c|c|c|c}
\hline \multirow{2}{*}{ Material } & \multirow{2}{*}{$\begin{array}{c}\text { Air void } \\
(\%)\end{array}$} & \multicolumn{2}{|c}{ Discharge time (s) } \\
\cline { 3 - 4 } & & Before & After \\
\hline Case 30-1 & 20.6 & 5.49 & 5.00 \\
Case 30-2 & 23.3 & 5.13 & 4.83 \\
Case 30-3 & 25.7 & 5.04 & 5.04 \\
Case 30-4 & 29.4 & 5.09 & 5.03 \\
Case 30-5 & 32.2 & 5.03 & 4.92 \\
\hline
\end{tabular}

\section{$i$ : hydraulic gradiẻnt, \\ $i_{c}$ : critical hydraulic gradient, \\ $c, n$ : constant.}

Fig. 3 gives the results of permeability tests for PAB. For the mixture with $32 \%$ air void, the flow is always in the turbulent state, while the flow state changes from laminar flow to turbulent flow with increasing hydraulic gradients for other cases. The permeability characteristics $k, c, n$, and $i_{c}$ obtained through experiments are summarized in Table 3. In the table, the permeability coefficient at a hydraulic gradient of $1.5 \%$, which is typical for airport runways ${ }^{6)}$, is also included.

Both proper gradation and density are vital to the permeability, and many kinds of relationships have been reported 9), 10), 11), 12), 13), 14). In general, the gradation can be characterized by the effective size $D_{10}$, mean aggregate size $D_{\text {mean }}$, and the percentage passing $0.075 \mathrm{~mm}$ sieve $P_{0.075}$, while the density might be characterized by the air void $V_{a}$. As the transverse surface gradient of airport runways is specified as $1.5 \%$ or less, the hydraulic gradient of $1.5 \%$ is considered to be pertinent for permeability calculations. Based on regression analyses of their relationship, Equation (3) was obtained with a correlation coefficient of $0.99\left(\mathrm{k}: \mathrm{cm} / \mathrm{s}, D_{10}: \mathrm{mm}\right)$.

$$
k_{i=0.015}=6.73 \times 10^{2} \cdot V_{a}^{2.79} \cdot D_{10}^{0.247}
$$

\section{(3) Applicability to base course}

\section{a) Durability against repeated loadings}

To study durability of PAB, which was defined here as the resistivity to permeability decrease, against repeated loadings, the permeability was measured before and after a wheel tracking test. The specimen for the test was made with two layers, a $50 \mathrm{~mm}$ thick dense graded asphalt surface (DGAS) mixture and a $100 \mathrm{~mm}$ thick PAB mixture, with $300 \mathrm{~mm}$ length and $300 \mathrm{~mm}$ width. Wheel loads were
Table 5 Water rise time through CTB

\begin{tabular}{c|c}
\hline Water level & Time (min) \\
\hline $20 \mathrm{~mm}$ from surface & 3 \\
$10 \mathrm{~mm}$ from surface & 8 \\
Surface in partial & 40 \\
Whole surface & 60 \\
\hline
\end{tabular}

Table 6 Input data for permeability calculation

\begin{tabular}{c|c}
\hline Item & Input data \\
\hline runway width & $80 \mathrm{~m}$ (with shoulders) \\
crack/joint spacing & $7.5 \mathrm{~m}$ \\
hydraulic gradient & $1.5 \%$ \\
PAB thickness & $50 \mathrm{~mm}$ \\
interval of rain & 3 days \\
drain duration & 7.2 hours \\
\hline
\end{tabular}

applied repeatedly to the specimen for one hour in accordance with a procedure that is similar to that described in reference 15) except that transverse wandering was provided. After the test and the removal of DGAS, the permeability of PAB was measured directly in accordance with reference 7).

The measured permeability was compared to that determined in the same way before the test. Table 4 shows the result for the time required to discharge $400 \mathrm{~cm}^{3}$ of water. As the loading has little influence on the discharge time, the permeability of PAB might not decrease after opening to traffic.

\section{b) Effectiveness against high groundwater}

An immersed wheel tracking test was conducted to evaluate the effectiveness of PAB against a high groundwater condition. The specimen consisted of the same two bituminous layers as in the wheel tracking test; namely, $50 \mathrm{~mm}$ thick DGAS and $100 \mathrm{~mm}$ thick base material. Two types of base materials, PAB and cement treated base (CTB) material that satisfy the specification ${ }^{16)}$, were used as a base course.

After repeated load applications, the bottom of DGAS on the CTB was stripped at a stripping ratio of $3 \%$, while no stripping was found in the PAB case. The former is caused by the capillary phenomenon through the CTB. This is shown in Table 5, which gives the time for the capillary water to rise to different heights in the CTB. Thus, PAB is appropriate for the high groundwater condition.

\section{c) Recommended mixture proportion}

Assuming that rainwater flows through PAB in the laminar state, the required permeability can be estimated with chart " $A$ " of reference 17), which shows relationships between the design infiltration rate and the drain path length. As a result, the permeability coefficient of PAB must be $0.14 \mathrm{~cm} / \mathrm{s}$ or larger under the condition shown in Table 6, which is typical of Tokyo International Airport. PAB with $20 \%$ air void clearly satisfies this requirement as 
seen in Fig. 3, but PAB with smaller air void might not provide adequate ability to retain permeability, as supposed from test results on porous asphalt surface mixtures. Modified asphalt ${ }^{5}$ should be used because even PAB with $20 \%$ air void does not have stability sufficient for a base course material ${ }^{15}$.

\section{POROUS ASPHALT SURFACE MIXTURES}

\section{(1) Material}

In accordance with the specification ${ }^{18)}$, aggregates with a maximum size of $13 \mathrm{~mm}$ were used for porous asphalt surface (PAS) mixtures; i.e., S-30 in PAB is replaced with S-13. Modified, high viscosity asphalt was used in consideration of its extensive use in road pavements.

Three air void ratios $(17,20$ and $23 \%$ ) were selected as mix proportions. The mechanical properties and aggregate characteristics are shown in Table 7 and Table 8 , respectively. The mix proportions were determined with asphalt runoff tests ${ }^{7)}$ and Cantabro tests ${ }^{7}$ in addition to Marshall stability tests.

\section{(2) Permeability}

Table 9 shows the permeability coefficient obtained with the procedure specified in reference 15) under turbulent flow conditions ${ }^{19)}$. The permeability increases with the air void as well as $\mathrm{PAB}$, while all cases satisfy the specification as a porous surface course material for roads ${ }^{5}$.

To clarify the influence of traffic loading on the permeability of PAS, the aforementioned in situ permeability tests were conducted before and after the immersed wheel tracking test. The results shown in Table 9 indicate that the permeability drops after the test regardless of the air void, in contrast to PAB. Although permeability decreases markedly in the range of lower air voids, the mix with $23 \%$ air void was similar to that of the PAB. Therefore, PAS should have an air void of $20 \%$ or more by considering permeability.

\section{(3) Applicability to surface course}

As the Marshall stability of PAS is lower than the specified value for an airport pavement surface course material ${ }^{16)}$, other characteristics related to traffic loading were studied. Table 10 shows the results of immersed wheel tracking test, raveling test ${ }^{15)}$ and wheel tracking test in comparison with data of DGAS mixtures for airport pavements ${ }^{18)}$.

All PASs showed no stripping in contrast with DGAS, and their durability against traffic loading under high groundwater conditions was adequate.
Table 7 Marshall stability test results of PAS

\begin{tabular}{c|c|c|c|c|c|c}
\hline Case & $\begin{array}{c}\text { Target air } \\
\text { void } \\
(\%)\end{array}$ & $\begin{array}{c}\text { Actual air } \\
\text { void } \\
(\%)\end{array}$ & $\begin{array}{c}\text { Density } \\
\left(\mathrm{g} / \mathrm{cm}^{3}\right)\end{array}$ & $\begin{array}{c}\text { Asphalt } \\
\text { content } \\
(\%)\end{array}$ & $\begin{array}{c}\text { Stability } \\
(\mathrm{kN})\end{array}$ & $\begin{array}{c}\text { Flow } \\
(1 / 10 \mathrm{~mm})\end{array}$ \\
\hline $13-1$ & 17 & 17.0 & 2.047 & 5.5 & 5.49 & 38 \\
$13-2$ & 20 & 19.9 & 1.985 & 5.2 & 5.09 & 38 \\
$13-3$ & 23 & 23.2 & 1.906 & 5.1 & 4.29 & 39 \\
\hline
\end{tabular}

Table 8 Aggregates characteristics of PAS

\begin{tabular}{c|c|c|c}
\hline Case & $\begin{array}{c}D_{\text {mean }} \\
(\mathrm{mm})\end{array}$ & $\begin{array}{c}D_{10} \\
(\mathrm{~mm})\end{array}$ & $P_{0.075}(\%)$ \\
\hline $13-1$ & 7.61 & 0.40 & 4.6 \\
$13-2$ & 7.94 & 0.65 & 4.4 \\
$13-3$ & 8.13 & 1.17 & 4.3 \\
\hline
\end{tabular}

Table 9 Permeability and discharge time of PAS

\begin{tabular}{c|c|c|c|c}
\hline \multirow{2}{*}{ Case } & Air void & Permeability & \multicolumn{2}{|c}{ Discharge time (s) } \\
\cline { 4 - 5 } & $(\%)$ & $(\mathrm{cm} / \mathrm{s})$ & Before & After \\
\hline $13-1$ & 17.5 & 0.09 & 7.94 & 16.95 \\
$13-2$ & 19.9 & 0.28 & 6.25 & 9.04 \\
$13-3$ & 22.9 & 0.45 & 5.32 & 5.87 \\
\hline
\end{tabular}

Table 10 Mechanical properties of PAS

\begin{tabular}{c|c|c|c|c}
\hline Case & Air void (\%) & $\begin{array}{c}\text { Stripping rate } \\
(\%)\end{array}$ & $\begin{array}{c}\text { Wear rate } \\
(\%)\end{array}$ & $\begin{array}{c}\text { Dynamic stability } \\
\text { (cycles/mm) }\end{array}$ \\
\hline $13-1$ & 17.0 & 0 & 1.8 & 6,600 \\
$13-2$ & 20.0 & 0 & 2.1 & 6,450 \\
$13-3$ & 23.2 & 0 & 2.6 & 3,791 \\
DG & 3.7 & 2.7 & 2.2 & 607 \\
\hline
\end{tabular}

The modified, high viscosity asphalt can increase the bonding strength between the aggregates and asphalt.

The wear rate increases, and the dynamic stability decreases with an increase of air void. The wear rate for an air void of $23 \%$ is larger than that of DGAS, while the dynamic stability of PAS is much larger than that of DGAS, regardless of the air void. Therefore, PAS should have an air void of $20 \%$ or less to sustain sufficient durability against traffic loading under both hot and cold conditions.

\section{CONCLUSIONS}

The followings are the main conclusions of the applicability of permeable asphalt base (PAB) and porous asphalt surface (PAS) mixtures to airport runways.

1) The flow state in PAB changes from laminar to turbulent with an increase of hydraulic gradient in the range of tested air voids (less than 30\%). As the critical hydraulic gradient is between 0.01 and 0.2 , the flow state in PAB of airport runways is considered to be laminar.

2) The permeability coefficient of PAB is influenced by both the air void and the effective 
size of aggregates, and that for a $1.5 \%$ of hydraulic gradient can be regressed with a high confidence level.

3) PAB maintains a sufficient permeability after repeated loading, and shows no stripping in immersed wheel tracking tests. PAB with $20 \%$ air void that contains high viscosity, modified asphalt could be used in heavy-duty airport runways even under high groundwater conditions.

4) PAS with $20 \%$ air void has not only sufficient permeability but also high durability against repeated loading when high viscosity, modified asphalt is used. Therefore, PAS could be used for the less trafficked portions of airport runways, even under high groundwater conditions.

\section{REFERENCES}

1) Cedergren, H.R.: Seepage, Drainage, and Flow Nets, John Wiley \& Sons, Inc., 534p., 1977.

2) Forsyth, R., Wells, G.W. and Woodstrom, J.H.: Economic impact of pavement subsurface drainage, Transportation Research Record (TRR), No.1121, pp.77-85, 1987.

3) Ridgeway, H.H.: Pavement subsurface drainage systems, National Cooperative Highway Research Program (NCHRP), Synthesis of Highway Practice, No.96, 38p. 1982.

4) Christopher, B.R. and McGuffey, V.C.: Pavement subsurface drainage systems, NCHRP, Synthesis of Highway Practice, No.239, 50p., 1997.

5) Japan Road Association (JRA): Manual for asphalt pavements, 324p., 1992 (in Japanese).

6) Civil Aviation Bureau, Ministry of Transport (CAB, MOT): Specification for Airport Civil Engineering Facilities, 1997 (in Japanese).

7) JRA: Guide for Pavement Tests (Supplement), 317p., 1996 (in Japanese).

8) Japan Society of Civil Engineers (JSCE): Reports on activities of pavement engineering research committee, 1997 (in Japanese).

9) Huang, Y.H.: Pavement analysis and design, Prentice Hall, Inc., 805p., 1993.

10) Crovetti, J.A. and Dempsey, B.J.: Hydraulic Requirements of Permeable Bases, TRR, No.1425, pp.28-36, 1993.

11) Randolph, R.W., Cai, J., Heydinger, A.G. and Gupta, J.D.: Laboratory study of hydraulic conductivity for coarse aggregate bases, TRR, No.1519, pp.19-27, 1996.

12) Yin, J. and Hachiya, Y.: Permeability of drainage base course materials at laboratory tests, Journal of Pavement Engineering, JSCE, Vol.3, pp.175-182, 1998.

13) Xie, H., Yao, Z., Tian, S. and Zhuang, S.: Permeability of asphalt treated permeable base materials, Chinese Journal of Highway and Transport, Vol. 13, No.2, pp.20-23, 2000 (in Chinese).

14) Yao, Z. and Xie, H.: Design of the asphalt treated subdrainage systems, 4th Annual Meeting of Shanghai Highway Society, pp.1-6, 1999 (in Chinese).

15) JRA: Guide for pavement tests, 1069p., 1988 (in Japanese).

16) CAB, MOT: Guideline on Airport Pavement Design , 147p., 1999 (in Japanese).

17) American Association of State Highways and Transportation Officials: AASHTO Guide for Design of Pavement Structures, Volume 2, 1986.

18) CAB, MOT: General specifications on Airport Civil Engineering Facility Constructions, 1999 (in Japanese).

19) Ohkawa, H., Sato, T. and Hokari, K.: Study on the estimation of permeability coefficient of drain asphalt, Journal of JSCE, No.478/V-21, pp.101-108, 1993 (in Japanese).

(Received March 26, 2001)

透水性アスファルト混合物の空港舖装への適用性

\section{八谷 好高・伍 石生・高橋 修}

航空機の大型化ならびに運航回数が増加するにつれ，空港舖装が水により受ける影響も著しいものとな る. 排水システムを用いることにより舖装の寿命を延ばすことが可能となるため, 交通量の多い大規模空 港の舗装ではこのシステムが必要になる，本論文では，舖装から雨水を排水するために用いられる透水性 アスファルト路盤材料と透水性アスファルト表層材料の特性について, 室内試験により検討した. その結 果, 両材料の空港舗装への適用性が明らかになった. 